\title{
Fatty Acid Composition of the Aerial Parts of Some Centaurea Species in Elazıg, Turkey
}

\author{
Tugce Erdogan ${ }^{1 *}$, Tuba Gonenc ${ }^{1}$, Ugur Cakilcioglu ${ }^{2}$ and Bijen Kivcak ${ }^{1}$ \\ ${ }^{1}$ Department of Pharmacognosy, Faculty of Pharmacy, Ege University, Bornova, Izmir, ${ }^{2}$ Department of Food Technology, \\ Pertek Sakine Genc Vocational High School, Tunceli University, Pertek, Tunceli, Turkey \\ *For correspondence: Email: tugce.fafal@ege.edu.tr; Tel: +90 232311 3965; Fax: +90 2323885258
}

\begin{abstract}
Purpose: To evaluate the fatty acid composition of six Centaurea species, viz, Centaurea behen, C. saligna, C. depressa, C. urvillei subsp. urvillei, C. urvillei subsp. hayekiana and C. aggregata subsp. aggregata, from Elazığ, Turkey.

Methods: Fatty acid methyl esters (FAMEs) of the oil extracts of four Centaurea species were prepared. The fatty acid compositions of Centaurea species were analyzed by gas chromatography (GC).

Results: Saturated fatty acids (SFAs) in Centaurea species and subspecies ranged from 24.61 $50.92 \%$ of their total fatty acid content, while monounsaturated fatty acids (MUFAs) were in the range of $3.40-37.96 \%$ and polyunsaturated fatty acids (PUFAs) $12.21-20.57 \%$. Palmitic acid C 16:0, oleic acid $C$ 18:1 $\omega 9$ and linoleic acid C 18:1 $\omega 3$ were the major fatty acids in all the species. Oleic acid was the main constituent of $C$. urvillei subps. urvillei and C. agrregata subsp. aggregata with a content of 26.92 and $50.92 \%$, respectively.

Conclusıon: The oil extracted from Centaurea species is a good source of essential fatty acids.

Keywords: Centaurea, Fatty acid, Palmitic acid, Oleic acid, Linoleic acid

Tropical Journal of Pharmaceutical Research is indexed by Science Citation Index (SciSearch), Scopus, International Pharmaceutical Abstract, Chemical Abstracts, Embase, Index Copernicus, EBSCO, African Index Medicus, JournalSeek, Journal Citation Reports/Science Edition, Directory of Open Access Journals (DOAJ), African Journal Online, Bioline International, Open-J-Gate and Pharmacy Abstracts
\end{abstract}

\section{INTRODUCTION}

Centaurea genus, 114 of which are endemic, is represented with 192 taxa in Turkey [1-3]. It is known as "peygamber çiçeği, zerdali dikeni, coban kaldiran, timur dikeni" in Turkey [3,4]. Many species of this genus have traditionally been used for their anti-rheumatic, diuretic, choleretic, stomachic, astringent, cytotoxic, antibacterial, antipyretic and tonic properties [46]. Flavonoids, steroids, volatile constituents, sesquiterpene lactones and fatty acids have been previously isolated from plants belonging to the genus [7-11]. Fatty acid, either saturated or unsaturated, is a carboxylic acid with a long aliphatic chain. Most naturally occurring fatty acids have an even numbered chain of carbon atoms ranging from 4 to 28 . Fatty acids that have carbon-carbon double bonds are known as unsaturated fatty acids whereas acids without double bonds are known as saturated fatty acids. They differ in chain length as well [12]. The fatty acid profiles of some plants from Turkey have previously been reported [13,14].

However there have been no reports on the fatty acid composition of Centaurea behen L, C. saligna (C. Koch.) Wagenitz, and C. aggregata Fish \& Mey. Ex. DC. aggregata. In addition to the foregoing species, the fatty acid composition of C. urvillei DC. subsp. urvillei DC., C. urvillei DC. subsp. hayekiana Wagenitz. and C. depressa 
Bieb which were previously investigated [15] were also comparatively analyzed in the present study. Therefore this study was designed to evaluate the fatty acid compositions of six Centaurea species, one of which (C. saligna) is endemic for Turkey.

\section{EXPERIMENTAL}

\section{Plant materials}

The aerial parts of Centaurea behen, C. saligna, C. depressa, C. urvillei subsp. urvillei, C. urvillei subsp. hayekiana and C. aggregata subsp. aggregata, were collected in July 2011 from Elazıg, Turkey. The plants were identified by Ugur Cakilcioglu (Elazığ Directorate of National Education, Elazığ, Turkey). Voucher specimens (nos. 1469, 1466, 1462, 1460, 1463, and 1458, respectively) were deposited in the Herbarium of Faculty of Pharmacy, Department of Pharmacognosy, Ege University, Izmir, Turkey.

\section{Extraction of oil}

The oil in the dried and powdered aerial parts (40 g) was extracted by Soxhlet extractor using petroleum ether $(400 \mathrm{ml})$ at $60^{\circ} \mathrm{C}$ for $6 \mathrm{~h}$. The solvent was evaporated in a rotary evaporator, and the oil obtained was esterified to determine fatty acid composition. The fatty acids in the total lipid were esterified into methyl esters by saponification with methanol (50\%) containing $5 \%$ sodium hydroxide at $100^{\circ} \mathrm{C}$ for $10 \mathrm{~min}$ and transesterified with $14 \% \mathrm{v} / \mathrm{v}$ boron trifluoride $\left(\mathrm{BF}_{3}\right)$ in methanol at $100^{\circ} \mathrm{C}$ for $5 \mathrm{~min}$ [16].

\section{Preparation of fatty acid methyl esters (FAMEs)}

The fatty acids in the total lipid were esterified into methyl esters by saponification with $0.5 \mathrm{~N}$ methanolic $\mathrm{NaOH}$ and transesterified with $14 \%$ $\mathrm{v} / \mathrm{vBF}_{3}$ in methanol at $100^{\circ} \mathrm{C}$ for $5 \mathrm{~min}$ [17].

\section{Fatty acid analysis}

The fatty acid methyl esters (FAMEs) were analyzed on a Hewlett Packard Agilent $6890 \mathrm{~N}$ gas chromatograph (GC), equipped with a flame ionization detector (FID) and fitted to a Supelco SP-2380 fused silica capillary column $(60 \mathrm{~m}$, $0.25 \mathrm{~mm}$ i.d. and $0.2 \mu \mathrm{m})$. Injector and detector temperatures were set at 250 and $260^{\circ} \mathrm{C}$, respectively. The oven was programmed at an initial temperature of $140^{\circ} \mathrm{C}$ and an initial time of 5 min. Thereafter, the temperature was increased up to $240^{\circ} \mathrm{C}$ at a rate of $3^{\circ} \mathrm{C} / \mathrm{min}^{-1}$. Total run time was $41.33 \mathrm{~min}$. Helium was used as the carrier gas $\left(1 \mathrm{ml} \mathrm{min}^{-1}\right)$. Identification of fatty acids was carried out by comparing sample FAME peak relative retention times. The results were expressed as flame ionisation detector (FID) response area in relative percentages. Each reported result is given as the mean of three GC determinations presented as mean \pm standard deviation (SD).

\section{RESULTS}

Twenty one fatty acids were identified in the six Centaurea species and subspecies. The fatty acid composition of the plant is shown in Table 1.

The major fatty acids with 16 and 18 carbons were determined to be palmitic, oleic and linoleic acids. Saturated fatty acids (SFAs) of Centaurea of all the species/ ranged from $24.61-50.92 \%$ of the total fatty acids, while monounsaturated fatty acids (MUFAs) were in the range $3.40-37.96 \%$, polyunsaturated fatty acids (PUFAs) were in the range $12.21-20.57 \%$. Except for $C$. saligna and C. urvillei subsp. hayekiana, palmitic acid was identified as the major component of the Centaurea species. Oleic acid, with 26.92 and $50.92 \%$, was the main constituent of C. urvillei subps. urvillei and $C$. agrregata subsp. aggregata, respectively.

\section{DISCUSSION}

Saturated fatty acids (SFAs) were detected in $C$. aggregata subsp. aggregata with $50.92 \%$ while C. urvillei subsp. hayekiana showed the lowest saturated fatty acid content with $24.61 \%$. Yildirim et al previously reported palmitic acid as the main fatty acid component of some Centaurea species [17] thus showing good aggrement with the results of the present study. Palmitic acid was the main SFA and ranged between 16.61 and $37.75 \%$. In agreement with the present results, palmitic acid has previously been shown to demonstrate the highest proportion in the SFAs of some Centaurea plants [15,17-20].

PUFAs ranged from 12.21 to $20.57 \%$ while linoleic acid content ranged from 0.41 to $17.40 \%$. The fatty acid composition of some Centaurea oils which was previously determined, indicate that linoleic acid content was 11.69 and $55.27 \%$ in C. rigida and C. kotschyi var. kotschyi, respectively $[15,18]$.

Oleic acid was the most dominant MUFA in all Centaurea species except for $C$. depressa. The level of oleic acid reached $25.12 \%$ in C. urvillei subsp. hayekiana. In a previous study, oleic acid was reported to be the main constituent of 
Table 1: Fatty acıd composition (\%) of Centaurea specıes ( $n=3)$

\begin{tabular}{|c|c|c|c|c|c|c|}
\hline Fatty acid & C. behen & C. saligna & $\begin{array}{c}C . \\
\text { depressa }\end{array}$ & $\begin{array}{l}\text { C. urvillei } \\
\text { subsp. } \\
\text { urvillei }\end{array}$ & $\begin{array}{c}\text { C. urvillei } \\
\text { subsp. } \\
\text { hayekiana }\end{array}$ & C.aggregata \\
\hline C 4:0 & $0.22^{\mathrm{a}}$ & - & 0.14 & 0.56 & - & 0.28 \\
\hline C 6:0 & 0.09 & 0.22 & 0.08 & 0.28 & - & 0.09 \\
\hline C 8:0 & 0.17 & 0.54 & 0.13 & 0.21 & 0.12 & 0.26 \\
\hline C 12:0 & 1.06 & 0.40 & 0.08 & 1.07 & 0.86 & 0.31 \\
\hline C 13:0 & - & - & 0.15 & - & - & - \\
\hline C 14:0 & 1.05 & 0.49 & 1.05 & 0.63 & 0.48 & 1.01 \\
\hline C 15:0 & 0.55 & - & 0.28 & 0.36 & 0.23 & 0.84 \\
\hline C 16:0 & 25.86 & 16.61 & 22.18 & 17.56 & 16.62 & 37.75 \\
\hline C 17:0 & 0.67 & 0.48 & 0.25 & 0.45 & 0.33 & 0.81 \\
\hline C 18:0 & 4.27 & 6.05 & 2.87 & 4.37 & 5.40 & 7.48 \\
\hline C 21:0 & 0.35 & 0.38 & 0.18 & 0.17 & 0.20 & 0.56 \\
\hline C 22:0 & 2.47 & 1.62 & 0.84 & 0.62 & - & 0.48 \\
\hline C 23:0 & 0.77 & 0.61 & 0.44 & 0.64 & 0.37 & 1.05 \\
\hline C 24:0 & 1.12 & - & - & - & - & - \\
\hline$\sum$ SFA $^{\mathrm{b}}$ & 38.65 & 26.91 & 28.67 & 26.92 & 24.61 & 50.92 \\
\hline C $18: 1 \omega 9$ & 9.72 & 19.53 & 7.96 & 10.71 & 25.12 & 3.40 \\
\hline C 20:1 $\omega 9$ & 0.84 & 0.53 & 13.81 & 0.33 & 0.37 & - \\
\hline C $24: 1 \omega 9$ & 0.14 & - & - & - & - & - \\
\hline$\sum$ MUFA $^{\mathrm{b}}$ & 10.70 & 20.06 & 21.77 & 10.71 & 25.49 & 3.40 \\
\hline C $18: 2 \omega 6$ & 8.23 & 11.52 & 13.6 & 12.68 & 17.40 & 0.41 \\
\hline C $18: 3 \omega 6$ & 3.08 & 2.89 & 2.24 & 1.84 & 1.05 & 3.78 \\
\hline C $20: 3 \omega 3$ & 3.62 & 4.28 & 3.51 & 1.78 & 0.96 & 5.37 \\
\hline C $20: 5 \omega 3$ & 1.47 & & 1.17 & 1.61 & 0.83 & 2.65 \\
\hline$\sum$ PUFA $^{\mathrm{b}}$ & 16.40 & 20.57 & 20.52 & 17.91 & 20.24 & 12.21 \\
\hline
\end{tabular}

C. ptosimopappoides and C. patuala oil $[18,19]$. Recently, oleic acid was claimed to be the major MUFA in the oil of C. kotschyi var. kotschyi, C. pterocaula, C. solstitialis subsp. solstitialis, C. triumfettii, C. urvillei subsp. urvillei and C. virgata collected from Konya, Turkey [15]. Similar to the obtained results, oleic acid was also identified as the major MUFA and linoleic acid identified as the major PUFA in selected Centaurea species [8]. Linoleic acid has been detected in the fatty acids derived from some Asteraceae species [21-23]. Oleic and linoleic acid have the capability to lower blood cholesterol levels. Intake of these fatty acids are promoted by nutritionists and the health professionals [24]. Oleic acid, with the ability of reducing low-density lipoprotein (LDL) levels and possibly increasing high-density lipoprotein (HDL) levels, is known as a monounsaturated fatty acid in normal diet [25]. The lack of dietary essential fatty acids such as linoleic acid has been implicated in the aetiology of diseases including cardiovascular diseases and their progression [26]. Linoleic acid cannot be synthesized by the human body and it is known to be essential for human body [27]. Linolenic acid with protective effect against heart disease has been shown to play a role in the development of the brain and retina [28].

\section{CONCLUSION}

PUFAs are beneficial to health and the oils obtained from Centaurea species with high content of PUFAs should be beneficial to human health. Furthermore, this oil may be useful as additives in food and health supplements. The oil of Centaurea species is a good source of essential fatty acids.

\section{ACKNOWLEDGEMENT}

The authors would like to thank the authorities of Ege University Faculty of Pharmacy Pharmaceutical Sciences Research Centre (FABAL, Izmir, Turkey) and Ege University Research Fund, Izmir, Turkey (grant no. 13/ECZ/031) for support for this work.

\section{REFERENCES}

1. Davis PH, Mill RR, Tan K. In Davis (Ed). Flora of Turkey and the East Aegean Islands. Edinburh University Press, Edinburgh, 1988; pp 489-501.

2. Güner A, Ozhatay N, Ekim T, Baser KHC. Flora of Turkey and the East Aegean Islands. Edinburh University Press, Edinburgh, 2000; 163. 
3. Wagenitz G. Centaurea L. In P.H. Davis (Ed.) Flora of Turkey and the East Aegean Islands. Edinburgh University Press, Edinburgh, 1975; $p 536$.

4. Baytop T. Türkiye' de Bitkilerle Tedavi (Geçmişte ve Bugün), Nobel Tıp Kitabevleri, Istanbul, 1999; $p 316$.

5. Yesilada E, Sezik E, Honda G, Takaishi Y, Takeda Y, Tanaka T. Traditional medicine in Turkey. IX: Folk medicine in Northwest Anatolia. J Ethnopharmacol 1999; 64: 195-210.

6. Sezik E, Yesilada E, Honda G, Takaishi Y, Takeda Y, Tanaka T. Traditional medicine in Turkey. X. Folk medicine in Central Anatolia. J Ethnopharmacol 2001; 5(2-3): 95-115.

7. Ahmed N, Bibi, R. Chemical investigation of Centaurea iberica. Fitoterapia 1979; 50: 199-200.

8. Tekeli Y, Sezgin M, Aktumsek A, Guler GO, Sanda MA. Fatty acid composition of six Centaurea species growing in Konya, Turkey. Nat Prod Res 2010; 24: 1883-1889.

9. Senatore N, Arnold A, Bruno M. Volatile components of Centaurea eryngioides Lam. and Centaurea iberica Trev. var. hermonis Boiss. Lam., two Asteraceae growing wild in Lebanon. Nat Prod Res 2005; 19: 749-754.

10. Shamyanov D, Akhmedov UA Saidkhodzhaev Al. Sesquiterpene lactones and other components of Centaurea iberica. Chem Nat Compd 1998; 34: 339340.

11. Dumlu MU, Gürkan EA. A new active compound from Centaurea species. Z. Naturforsch C 2006; 61: 44-46.

12. IUPAC Compendium of Chemical Terminology (2nd edn). International Union of Pure and Applied Chemistry. 1997. ISBN 0-521-51150-X; 2007; pp 10-31.

13. Unver A, Ozcan MM. Fatty acid composition of seed and pericarp of sumach (Rhus coriaria L.) grown wild in different regions of Turkey. J Food Agric Envir 2010; 8(1): 31-33.

14. Yıldırım FA, Yıldırım AN, Askin MA, Kankaya A. Total oil, fatty acid composition and tocopherol content in kernels of several bitter and sweet apricot (Prunus armenica Batsch) cultivars from Turkey. J Food Agric \& Envir 2010; 8(3-4): 196-201.

15. Tekeli Y, Zengin HG, Aktumsek A, Sezgin $M$. Comparision of the fatty acid compositions of six Centaurea species. Chem Nat Comp 2013; 49(3): 496-498.
16. IUPAC Standards methods for analysis of oils, fats and derivatives. 6th ed. Pergamon Press, Oxford, 1979; pp 59-66.

17. Yildirim N, Sunar S, Agar G, Bozari S, Aksakal O. Biochemical and molecular characterization of some Centaurea species growing in the Eastern Anatolia region of Turkey. Biochem Genetics 2009; 47: 850859.

18. Aktumsek A, Zengin G, Guler GO, Cakmak YS. Screening for in vitro antioxidant properties and fatty acid profiles of five Centaurea L. species from Turkey flora. Food Chem Toxicol 2011; 49: 2914-2920.

19. Zengin G, Cakmak YS, Guler GO, Aktumsek A. In vitro antioxidant capacities and fatty acid compositions of three Centaurea species collected from Central Anatolia region of Turkey. Food Chem Toxicol 2010; 48: 2638-2641.

20. Zengin G, Aktumsek A, Guler GO, Cakmak YS, Yildiztugay E. Antioxidant properties of methanolic extract and fatty acid composition of Centaurea urvillei DC. subsp. hayekiana Wagenitz. Rec Nat Prod 2011; 5(2): 123-132.

21. Orhan I, Sener B. Comparative fatty acid analysis of Telekia speciosa. Chem Nat Compd 2003; 39: 244245.

22. Tsevegsuren N, Aitzetmuller K, Vosmann K. Occurrence of-linolenic acid in Compositae: A study Youngia tenuicaulis seed oil. Lipids 1999; 34: 525-529.

23. Zhusupova GE, Artamnova NA, Abilov ZHA. Fatty acid composition of roots of certain plant species of the genus Limonium. VIII, Chem Nat Compd 2007; 42: 602-603.

24. Johnson GH, Fritsche K. Effect of dietary linoleic acid on markers of inflammation on healthy persons: $A$ systematic review of randomized controlled trials. J Acad Nutr Diet 2012; 112: 1029-1041.

25. Parikh P, Mcdaniel MC, Ashen D, Miller JI, Sorrentino V, Chan V, Blumental RS. Diets and cardiovascular disease: an evidence-based assessment. J Am Coll Cardiolo 2005; 45: 1379-1387.

26. Goldberg G. Plants: Ciet and Health. Blackwell Science Published, Oxford: 2003.

27. Brown JE. A critical review of methods used to estimate linoleic acid 6- desaturation ex vivo and in vivo. Eur. $J$ Lipid Sci Tech 2005; 107: 119-134.

28. Connor WE. $\alpha$-Linolenic acid in health and disease. Am J Clin Nutr 1999; 69: 827-828. 